\title{
Mario Hibert
}

University of Sarajevo

\section{Critical Literacy - Open Values, Imaginary Rationalities}

\begin{abstract}
This papers aims to emphasize the importance of discussing the relationship between positivism, critical pedagogy and the politics of new media production of information and knowledge, claiming that the critical information divide is far more problematic than the digital (divide). In other words, if standardization of information literacy competencies shows its limits for upholding unbiased authenticity and relevance, then such a position also asserts a deficit in recognizing focal points needed in analysing the digital epistemology of today. The latter should encompass advocacy of critical media, literacy and ethics as the core components for socially responsible production and distribution of information in the new public domain: Internet. When practices of collaborative production of knowledge or $\mathrm{p} 2 \mathrm{p}$ - commons based production - is neither fully understood nor actualized in contemporary education, then free/open distribution of (digital) commons is prevented by instrumentalized depolitization (culturalization) discourses in a commodified information society. For that reason, I argue for denunciation of information literacy models through the lenses of Paolo Freire's concept of a banking model of education, hacktivism, as well as Samek's argument that "there is nothing more practical than learning how to build the self-confidence to weigh in with professional opinion and defend it as critique (not obstructiveness)."
\end{abstract}

This is an Open Access article distributed under the terms of the Creative Commons Attribution 3.0 PL License (creativecommons.org/licenses/by/3.0/pl/), which permits redistribution, commercial and non-commercial, provided that the article is properly cited. (C) The Author(s), 2014

Publisher: Institute of Slavic Studies, Polish Academy of Sciences

Editor in chief: Jolanta Sujecka

Conception and academic editing of this issue: Maciej Falski 
Keywords: critical pedagogy; critical library instruction; information literacy; new media; hacktivism; commons;

\section{Introduction}

A dominant narrative of the $21^{\text {st }}$ century by which a global community A extends its present consciousness on "collective identity" has been inaugurated with notions of digital media networking. Without a doubt, such a normative for communicative digital presence is to be seen as a prevailing form of social redesign in which growth of informatization serves as a substitute for industrialization imaginary, cyclically decompensated in allegedly post-political narrative of post-industrialism. The level of civilizational advance is being judged by democratization 2.0./3.0. effects (or iPod liberalism ${ }^{1}$ as suggests prominent cybersceptic Evgeny Morozov), whereby figurations usually remain naively neglected whenever discussions slip into contemporary educational discourses' avoidance of critically points on political, economic, social and cultural phenomena of new media realities. Digital natives or genuine speakers of a generation raised in the context of new media technology are dwelling now in an era when further divisions are to be found at the level of critical information literacy. As long as information society circumvents the realities of information and knowledge production/distribution as commons ${ }^{2}$, and whenever we fall in the gap to both, theoretically and practically, we avoid thinking as commoners in maintaining the world of libraries and we reduce vocational care in shaping of power dynamics among hierarchies of dependent and vulnerable. If

\footnotetext{
1 Morozov's ironic phrase: "Drop iPods not bombs!" lucidly demonstrates the limits of cyberutopianism equaled with the idea that every holder of new technological innovation will instantly love liberal democracy. His book "The Net Delusion: The Dark Side of Internet Freedom" criticizes the notion that technology equals liberation opting for cyber-realism sobriety having no expectations of a radical shift in the value system if being just pressured from the Internet alone. See more: Morozov, Evgeny. The Net Delusion: The Dark Side of Internet Freedom. New York: PublicAffairs, 2011; Morozov, Evgeny. "How the Net aids dictatorships". TED (July, 2009). Available at: http://www.ted.com/talks/evgeny_morozov_is_the_internet_what_orwell_feared. html (14.02.2010).

2 According to commons paradigm it has its history in rooting political change, public policy and cultural transformation which now seen on a global scale, with the Internet hosting infrastructure for all sort of commons (free/open source software, p2p sharing, access to open scholarly communication) and may indicate novelty in commons paradigm, there is no master inventory of commons. The commons paradigm which is increasingly attracting more and more attention, in its old practice teaches emancipation through self-provisioning, production, consumption and governance put together, and presumes that value does not equal values (value in an economic sense, while values in a humanistic sense). See more:

Bollier, David, Helfrich, Silke (eds.) The Wealth of the Commons. A World Beyond Market and State. Commons Strategies Group. Levellers Press, 2012.
} 
multifaceted literacies are not gained in-between teaching on diversity in "slow education"3 (Samek 2013), yet unbundled as firm and completed skills, monologization of interactive communicational landscapes, crucial to the idea of commons, is likely to happen. This will remain undiscovered as like tunnels of a deep web in open learning, revealing and recognizing that the power of having a voice in cyberspace rests on those who would listen.

Examining literacy temptations and capabilities in "altering the narrative" (Ruggerio 2012: 10) needed for "challenging the political nature of government repression" (ibidem: 14.), echoing, librarians' and hackers' ethics, may be needed for reading this paper as a critical quest for integrity values. ${ }^{4}$

\section{Value literacies: critical pedagogy and library instruction}

An emergent third phase in class struggle represents: “...struggle among the class of vectoralists (those who control flows and vectors of information by strategies of intellectual property regimes...) and the class of hackers understood as subjects of networked communication who are convinced that vectors of information might be used in a way that is not dependent on property regimes" (Wark 2004) opens up this new born antagonism. It rests on a dichotomy of enclosure/openness of information, communication, learning, and knowledge literacy of a new generation which is treated exclusively as promoting careerist competencies and expertise in handling information and communication technology, yet lacking awareness of complex relationships among information resources, tools, platforms, and ideological agendas embedded in social and political character of production and distribution of knowledge in cyberspace. The global and decentralized nature of the Internet creates a redefined domain for civic mediation; therefore information literacy crashes on educational models by which netizens ${ }^{5}$ are not treated as a generation needing to understand its

\footnotetext{
3 In her latest article about library neutrality and concomitant dilemma over what constitutes a library issue, Toni Samek asks for diversity and inclusion processes that acknowledge a tripartite of sister core library values (diversity, intellectual freedom and social responsibility) in changing learning environments.

4 Critical librarianship is here used as a methodological introduction to hackers and librarians' ethics, their converging and diverging, among private/public, media/memory, freedom/access, information/communication or critical pedagogy orientation.

5 According to Mark Poster netizen might be the formative figure in a new kind of political relation and in contrast to the citizen of the nation, the name netizen is often given to the political subject constituted in cyberspace. See more: Poster, Mark. "Citizens, digital media and globalization.” Mots Pluriels No. 18. (Aug. 2001). Available at: http://motspluriels.arts.uwa.edu. au/MP1801mp.html (29.11.2009).
} 
proactive components. In light of waves of public protests across the global media, memory, and politics our configuring of the future of commons is lingering. Open production and distribution of digital resources asks for new rationalities, moreover, a complexity of disciplinary discourse on information literacy which begins with acceptance of its critical framework for an ongoing project dealing with literacy of today.

Although frequently viewed and delivered as a method, information literacy should be rather seen as a process of understanding complexities in teaching and providing skills; values and knowledge that may provide for a more productive and responsible professional and civic life in networked society. So instead of perceiving information literacy as a compound of technical and mechanical skills, even more, a pure transfer of a fixed set of instructive references, it is important to see it moving towards a larger comprehension of structure and content of founding literature. Organic construction of literate reasoning does not depend on hierarchical imposition of neither technique nor strategy developments, but ideas that include appreciation for transformative values in multiplicity of perspectives. In other words, if we are to deploy information literacy a as strategy for another old school "hacking" in teaching, as skilled training for searching only for "relevant" resources, then we could easily be led astray when not considering social, political, economic and moral relationships among information production and distribution as well as digital divides in participatory globalized networking. Invoking here the basics of critical pedagogy seems highly important, since it draws attention to questions concerning who "has control over the conditions for the production of knowledge, values, and skills which illuminates how knowledge, identities, and authority are constructed within particular sets of social relations" (Giroux 2012). In that light I argue that enhancement of users' (researchers, students, citizens) outputs as well as content users' performances, moreover, their behaviour, depends on our commitment to strive for information literacy instructors, even better, librarians who are not wedded only to techniques of searching and organizing information, but those who would engage in the betterment of individual and social arrangements through critical usage of information and communication technology and its evolving contexts.

Researches in the domain of a relatively new scientific field of media pedagogy are indispensable for understanding the political connotation of the networking which embodies a civic ideal of bottom-up democracy and an intellectual ideal of generous curiosity, aspects which James Grimmelmann finds in the writing of David Post and Jonathann Zittain, using their work to further explain the Internet's "magic", as the combination of private control and open-to-all common access, whose 
semicommons structure, its dynamic, interdependently interplays in creating enduring tension over property rights (Grimmelmann 2010). Borrowing the notion of semicommons from Henry Smith to say that the Internet has been designed and used in ways that count on immense openness and distribution, therefore mass collaborativity, may lead to sustainability of open (digital) commons. Accordingly, digital, bottom-up democracy Free Culture should be viewed through a prism of educational capacities to enable users (students, teachers, citizens) to upgrade their awareness of what new media landscapes imply, as well the logic of New Public Management ${ }^{6}$ at the global, networked scale. For that reason, reminding ${ }^{7}$ ourselves about the emancipatory values of Paolo Freire's antipedagogical concept of critical pedagogy ${ }^{8}$ (in which the term "narrative disease" stands for learning models in which teacher and student are not dehierachized) warns us about non critical, passive relationships in regard to now openly decontextualized learning techniques (use of information resources, methods, and tools) for its ideological instrumentalization that promulgates neutralization discourses. Education as a political and

New Public Management is seen as the model of deregulation and commercialization of
knowledge which could be recognized in science, economy, politics, and education. About the
problems of such shift in public policies (especially, merkantilization of education) which led
to market and profit driven educational reforms Henry Giroux and Michael Apple wrote vigor-
ously during eighties. Henry A. Giroux argues that "new public philosophy" undermines ef-
forts for critical thinking of global social and political relations among students: "....schools
and universities become important only when provide knowledge, skills, and social practices
indispensable for production of work force in growing and complex technological economy."
See: Giroux, Henry A. "Public Philosophy and the Crisis in Education." Harvard Educational
Review Vol. 54. No. 2. (1984). 7 Hansen and Mitchell explains how notion of memory has a key role for critical media studies since it reveals basic importance of media theory as collective singularity, or convergence of psychological, social and technical fields. "This is one reason that we take memory to be a keyword in media studies. It is one of those terms that reveal vividly the need for a theory of media as a collective singularity, a convergence of psychological, social, and technical domains. Memory, which is usually understood as an interiorized and innate psychological faculty, has, from the standpoint of media studies, been understood as a crossroads of aesthetics, technology, and society since ancient times." See more: Hansen, Mark B. N., and William J. Thomas Mitchell. "The introduction to Critical Terms for Media Studies." Critical Terms for Media Studies. Eds. Hansen, Mark B. N., and William J. Thomas Mitchell. Chicago: University of Chicago Press, 2010.

Available at: http://www.press.uchicago.edu/Misc/Chicago/532554.html (12.05.2013).

8 Freire's concept of critical pedagogy is a form of opposing to conventional education that adjusts human to society by inhibiting its personal abilities and needs to proposed authoritarian norms. Critical pedagogy as Education for liberation stands for humanization, democratization, anti-imperial and anti-military goals. The central axiom of Freire's writing emphasize that education is never neutral. See more: Freire, Paolo. Pedagogija obespravljenih. Zagreb: Odraz, 2002; See more at: http://www.freireproject.org/; http://www.freire.org/paulo-freire/conceptsused-by-paulo-freire/. 
ethical act therefore shows the gap which librarians as information literacy instructors should bridge by their ability to handle so called electronic contact zones (Torrell 2010: 94). Teaching conflicts in the domain of cyberspace, according to Torrell, means critical inclusion of students in new media spaces which are seen as zones of contact pedagogy; vitally important for moving towards the information literacy of a new generation of digital natives. Offering a systematic approach to essential components for understanding critical information literacy basics and its importance for improving skills of learning communities, Drabinski, Kumbier, and Accardi further deeply engage us in seeing how contributing to literacy enhancement rests on fundamental notions found in librarian instruction in critical pedagogy (Accardi, Drabinski, and Kumbier 2010: ix-xiv). They point out that in order to situate critical information practice, we should first articulate the stance close towards Paolo Freire's writings and serve its crucial intolerance towards positivism - aka resistance to authoritarian discourses - in our classroom education. Consequently, to support and advocate pedagogy of multiliteracies in the digital domain (visual literacy, electronic literacy, digital literacy, media literacy, and technological literacy) it should be clear why the essentials of literacy cannot be measured by the set of universally applicable standards, since the very notion of literacy resides in the phenomenology of differences, specifically cultural, political, and economic systems which in their historical momentum demonstrate its updated ideology of power.

Librarians' instructional skills are now more than ever related to the realm of democratizing technology and new realities of its accommodation. The diversity of technological demands and the diversity of online communities which are rapidly expanding and changing, consequently push librarians over the boundaries of their traditional perceived sphere of expertise, making them obsolete when not redefining their roles as important guides through emerged landscapes of information society. Librarians are not only enabling users to successfully search, evaluate and use educational sources, but actively participate in new knowledge creation while never "losing from their mind" issues related to humanizing the digital divide. Or do they? In the "Atlas of New Librarianship" David R. Lankes emphasizes that in order to accomplish its 21 st century mission, librarians should facilitate knowledge creation in their communities by introducing the idea of conversational literacy: "...if learning is an active set of agreements and conversations, then simply providing access to information is insufficient to fulfil our mission!" (Lankes 2012: 222). Do librarians fluently enter into the domain of traditional publisher services, forge new alliances with its users, and advocate new directions in scholarly information access, etc., 
even more teach effective negotiating of new information production and dissemination practices, realizing new productive freedoms in information/ knowledge commons? Librarians' close relationship to the very ethical dimensions of combating the increasing commodification of information are, in other words, a force that publicly provides a task of conceptualizing literacy in digital era. ${ }^{9}$

On the other side, linking and reminding users to what is already known, building knowledge through conversation, revealsanother crucialimportance in information literacy instruction that presupposes dealing "...not only with extensions of the human sensorium, but with their introjections into the structures of feeling and forms of life that constitute human subjectivity and collectivity" (Hansen, Mitchell 2010: xviii). For that reason, supporting students', scholars', citizens' or employees' memory can be reached only when creating learning environments that converge psychological, social, and technical domains. Moreover, scaffolding future information creation assumes active professional engagements in contributing to the idea of greater equity of information access. ${ }^{10}$ Besides reminding us that the notion of "information literate" originally relates to, hopefully well-known, librarians' professional response to advanced technological change and proliferation of information, it is not insignificant to particularly underline how librarianship is too often burdened with stereotypes and prejudices that could be traced back to a traditional, positivist paradigm of the profession in which librarians are seen as knowledge gatekeepers, the ones who create and maintain order - which becomes the end in itself. Even when it is not openly demonstrated and uttered, postmodern epistemological foundations of library practices are rarely used. Even when admitted, that we forget or fail to remember ricochets of its imaginaries (as I was discovered, for example in Celeste West's heritage of radical librarians' social responsibility or Alberto Manguel's meditations on libraries, reading, and writing) ${ }^{11}$ its undivided irrational components or floating signifiers of uneven political economy simulacra emerge. Freedom issues in knowledge production and distribution in networked society and examination of its praxis is not trusted to librarians' whether or not its roots trace theoretical and professional

\footnotetext{
9 Or to put it differently, how is it orientated to the phenomena of the Internet as "architecture of innovation" and does it open its subversive logical codes, and if so - when and where?

10 Dealing with the changing nature of authorship, authority, commons, supporting online content publishing (for example, open access initiatives, open licensing, open source software, etc.) to name just a few critically important areas in which librarians could practice information ethics and social responsibility.

${ }_{11}$ She Was a Booklegger: Remembering Celeste West. Eds. T. Samek, M. Lang \&K. R. Roberto. Duluth, MN 2010; Manguel, Alberto. A Reader on reading. New Haven; London: Yale University Press, 2010.
} 
awareness. It may be that it is not heard because of the increased digital media "do-it-yourself" buzz in which literacy models dissect researches at the level of meta-competencies out of diversity of contexts. Although a majority of traditional library instruction chiefly emerges from the basic and pyramidal information literacy concepts focused on what could be named "the nature of standards" (seeking, evaluating, and use), particularly in regard to academic the environment, understanding processes of information retrieval and reception, abilities to locate, evaluate, and use information as a lifelong learning agenda is not anymore vertically transferred. Riding on that wave, native in generating information literacy attitudes and skills, as well as socio-political and ideological dimensions of information and knowledge consumption and production, are privatised or likely represented as beneficiary: "...like the representation of libraries as neutral institutions and services, information and information literacy are similarly represented as unproblematic, a theoretical, and apolitical" (Kapitzke 2003). With the development of increasingly sophisticated information and communication technologies, the role of the librarian as a fact provider is extremely difficult to maintain, therefore interpretation, filtering, and evaluation of information, guidance burdened with the creation of new orders developed and enacted by the capabilities of computer searching, file sharing, and $\mathrm{p} 2 \mathrm{p}$ navigating (or just assisting in open knowledge production and distribution) overpower the pre-existing order of the library that comprises its catalogues and indexes: “...the experience of the multicursal maze does not lead to a particular answer located in a specific text but rather the creation of new rationalities that define the usefulness or worthlessness of any specific text" (Radford 2003). Instead of conceptualizing literacy as a neutral, discrete, context-free skill (as something that can be measured by a universally-applicable set of standards), recognition of literacy (and its multitudes developed in response to new technologies and new media) as a culturally-situated phenomenon, embedded within specific social, political, and economic systems, is subject to (and potentially constitutive of) the power relations and ideologies that define particular moments of history. It suggests and urges us to think of information literacy within larger contexts of global information-based, knowledge economies. In other words, "...because of its positivist philosophical orientation, the information literacy framework is incompatible with emergent concepts of knowledge and epistemology for digital and online environments...view of knowledge and learning constitutes a positivist epistemology in which there are singular physical and social realities, or 'worlds', separate from the student and accessible through language" (Kapitzke 2003). Subsequently, media can no longer be dismissed as neutral or transparent, subordinate 
or merely supplemental to the information they convey, their social, economic, political and cultural agency in deregulated, de-hierarchized, and decentred virtual reality environments, yet their ambiguity, asks for not only empirical but interpretative methodological approaches. Consequently, if we acknowledge that media determines our situation then the shift from media as an empirical collection of artefacts and technologies to media as a perspective for understanding...reasserts the crucial and highly dynamic role of mediation - social, aesthetic, technical, and (not least) critical." (Mitchell, Hansen 2010). What we should then learn from the poststructuralist critique, critical pedagogy and critical librarianship is therefore essential for the ongoing and future debates around information literacy instruction.

\section{Hacking causes: literacy reinvented}

Privileges obtained in the proficiency of skilful digital labour might be followed by acknowledgment that education when understood as reproductive careerism, promulgates, as its focal social function, the appropriation of cultural capital which furthermore continues stratification at the level of literacy. Arising responsibility issues for librarians, teachers, and educators in general are to be found at the final stage of this discussion for they all stand at the distribution chain-end, starting or not critical instruction that could serve open resistance to pedagogical instrumentalization.

Or as in hacking, when described as "playful cleverness" (Stallman 2010) and "persistence in gettin' the job done", we nevertheless use terms of freedom to differentiate either wearing it as the proofed "badge of honour" or like in the manner of sensational, "...popular press, however, the connotations of 'hacker' are most often negative, or at minimum refer to illegal intrusion of computer systems. These differences point to the various meanings and multiple histories associated with the terms hacker and hacking." (Coleman, forthcoming 2014). Moreover, Coleman's anthropological insight might correspond its concordances with hacker ethics read as liberal critique from within liberalism: "hackers have built a dense ethical and technical practice that sustains their productive freedom, and in doing so, ...they extend as well as reformulate key liberal ideas, access, free speech, transparency, equal opportunity, publicity, and meritocracy" (Coleman 2012: 3).

In having such discussions, about scepticism grown within liberalism, our laboratory of library and information science curriculum, pedagogy, and technology mediation in transferring literacy assumes that in fostering productive freedoms librarians, teachers, and citizens share with hackers the same responsibility for upholding civil liberties: free speech privacy, and access. In lacking critical pedagogy approaches, we are about to miss 
how hackers' social and technical practices focus not only on the ethical philosophy of F/OSS (Free/Open Source Software) but also "on the importance of knowledge, self-cultivation, and self-expression as the vital locus of freedom." (Coleman 2012: 3). Due to attenuance in passionate discussions about humanistic episteme, academia might have already been lost for tracing beliefs in hacking the "freedom in the commons"12. While Benkler warns that solutions that the Internet makes possible are radically different from those that dominated the twentieth-century debate, so as up-to-date regulatory solutions that effect government abuse and political manipulation he expresses his adherence with the possibility of sustainable, widely accessible, and effective communications of individuals and groups, organized on- or offline in direct democratic discourse (Benkler 2003). Decentralized and nonmarket, peer-to-peer information production is seen as space free of the laws developed to support market- and hierarchybased production. How ready law and policy were in accommodating newly emerging ethics of emerging modes of production is probably best resumed in the banality of political morality of digital era. ${ }^{13}$

Addressing the notion of power, as well as an eternal recurrence of demands for democratization of social and economic life, hacktivists redefine boundaries of technology, fusing politics and technology into

\footnotetext{
12 Professor of Law, Yochai Benkler, author of the term 'commons-based peer production' explains "how fundamental social aspects of the emerging economic-technological condition of the networked information economy: the economic - concerned with the organization of production and consumption in this economy, and the political - concerned with how we pursue autonomy, democracy, and social justice in this new condition." Benkler thoroughly explains how radical decentralization of information production promises "the correction of some of the main maladies of the electronic mass media-the centralization of power to make meaning, the in-creased power of corporate interest in influencing the agenda, and the inescapable sound-bite character of the discussion. See more: Benkler, Yochai. "Freedom In The Commons: Towards Political Economy Of Information.” Duke Law Journal Vol. 52:1245 (2003). Available at: http://scholarship.law.duke.edu/cgi/viewcontent.cgi?article=1191\&context=dlj (accessed 23.4.2010). ${ }_{13}$ Here is where I would like to refer to the tragic death of Aaron Swartz and his struggle to defend public good by fighting censorship in technology, policy and copyright law. A. Swartz was programmer and activist who took his own life on 11 January 2013 at the age of 26 after being faced with federal charges that he violated the Computer Fraud and Abuse Act. By referring to misbalance or injustice in criminal prosecution and Internet activism (labeled ,piracy', ,hacking, or ,freedom fighting)' which is still "haunting”, viral public spaces concerning Aaron's "case", might be proving why cyber activism should extend, as Coleman notices, "over esoteric perception of hackers community (grounded in technology and its material practices) and is to be examined in its concerns with broader, culturally familiar vision of freedom, free speech rights, and liberalism..." (Coleman, 2013). Coleman describes how the figure of a hacker is targeted by the Computer Fraud and Abuse Act, enacted in the United States in 1986, becoming the weapon of choice to prosecute them: "since the mid 1980s, the U.S. government has tended to criminalize hacking under all circumstances, unwilling to differentiate between criminal activities, playful pursuit, and political causes." (Coleman 2014).
} 
the information ethics domain. Knowledge as the process, in the spirit of hacktivism activates a counter-hegemonic thirst for the common voice in regard to defending free speech substance that is, probably, most notably present in the Free Software Movement. Stallman's dedication to resistance in a collaborative networked environment aims a blow at the vital nerve of corporatism by proving software that may not be expropriated from the community's hands. Open commons for free speech may not be confused with corporative capitalism of smart devices that swallow our privacy together with agendas that invigorate neither anarchistic, nor socialistic, even capitalistic, political orientations, but negotiates them all in the spirit of critical pedagogy hacktivism. Openness, peer-to-peer surveillance of sharing, or any other ongoing occupying manifestation of anomaly, reveals layers of different facets in capitalist globalisation: "...the general tendency of today's global capitalism is towards further expansion of the market, creeping enclosure of public space, reduction of public services (healthcare, education, culture), and increasingly authoritarian political power" (Žižek 2013).

Thinking of recognition of Aaron's laws ${ }^{14}$ invokes further disproportion in literacy instructions over corruption and injustices of "imaginary futures" of liberalism. Focusing on social aspects of new media, we are to ask ourselves which kind of critical (media) education enables students to become information literate in the age of networking, hacking, and freedom fighting. A class of digital practitioners in participatory networks urge us to explore cyber-freedoms as a central topic in research in the humanities and humanistic social sciences. Therefore, whenever insisting on epistemic backgrounds that approach its humanistic foundations, whenever we remember our teachers, martyrs, and believers of a shared social-ecological

\footnotetext{
14 In his appeal to us not to be pathologized, the life and death of Aaron Swartz, Lawrence Lessig, a Roy L. Furman Professor of Law and Leadership at Harvard Law School, shares his thoughts on hacking as use of technical knowledge to enhance public good, explaining the importance of what he called 'Aaron's Laws'. Furthermore, as recently proved in the interview with Cory Doctorow (SF writer, journalist, blogger, technology critic, and lecturer) remembering how Aaron matured and was able to contribute to the networking literacy era, Cory remembers Aaron's vision of public interest hacking repressed after his invigoration with the Internet as well as public access to commons topic, in the narrative before his final facing with charges raised under the Computer Fraud Abuse Act.". Lessig concludes his speech with the phone call with the famous German director telling him that Aaron's death reminds him about the "strangely fascist spirit", "Die Andersdenkenden", "..those who think differently...being destroyed without any mercy, as if mercy were somehow a sign of weakness": on which Lessig warns by asking us to remember what are Aaron's Laws. See more: http://www.law.harvard.edu/news/2013/02/lessigchair-lecture-aarons-laws.html; or www.craphound.com (Cory Doctorow's official web page). http://blip.tv/lessig/aaron-s-laws-law-and-justice-in-a-digital-age-6535852
} 
system, we were rewriting the "Class of the New"15 biographies. Richard Barbrook's reminds us that the new social class emerging from the networked workplace needs integrity in teaching dominant methods of organizing labour: "the commodity" or the "gift". ${ }^{16}$

Multitudes of resistance and repression found in media production determine our situation. As the humanistic gap deepens, market orientated curricula are being systemically built into classrooms as a model of biocybernetical reproduction of mediatization or privatization under the flag of techno-scientific democracy paradigm. And so we approach the libertarian dilemma: "Do we protect the freedom of the individual citizen to disseminate knowledge for the benefit of other individuals to make informed decisions in the marketplace? Or do we protect the rights of corporations to restrict access to knowledge only to those individuals who can afford it by dint of economic resources, or membership of a university?" (Price, 2013).

A literate citizenry in the age of spectacle is not comprised of those people who see, but read how to work at a distance from the "banking mode of education" that Paolo Freire believes prevents creativity in teaching critical literacy.

Last summer I talked with Toni Samek, teacher activist, critical pedagogist, and library ethics essentialist who answered one of my interview questions as follows: "...teaching, in its broadest sense, involves much more than classroom pedagogy." 17 It made me think of the importance of not deteriorating the laboratories of our classrooms, our own rooms, with new public ideology and hidden curricula, (that both, converge and diverge, in "profounds of educational debate: 'Whose knowledge is of most worth?" (Apple 1990: vii)) and that we should continue striving to build self-confidence in the immateriality of boundaries and escaping mechanisms of academic reproduction in literacies not yet refocused and defended as knowledge commons. Too much distortion prevents us from understanding our limitless possibilities as well as what is threatening us,

15 I am alluding here to Richard Barbrook's book "The Class of the New" in which he collected quotations from authors who in different ways attempt to identify an innovative element within society: 'the class of the new' (from Adam Smith's 'Philosophers' of the late 18th century, down to the Richard Florida’s 'Creative Class'). Available at: http://www.theclassofthenew.net/(12.7.2013). 16 Barbrook's critique's emphasizes actual points on technological determinism found both in corporatist commodity economy as well as in Californian ideology of new media activists. For further essential reading one should consult his openly licensed book "Imaginary Futures: From Thinking Machines to the Global Village" from Pluto Press for which he was awarded with the Marshall McLuhan Award for Outstanding Book in the Field of Media Ecology in 2008. See: http://www.imaginaryfutures.net/book/

17 Professor Toni Samek, interviewed by Mario Hibert, 2012. (Pending publication). 
critical literacy understanding of knowledge as commons. The new types of freedom emerging from its semicommons structure should not remain just a hypothesis of technological win: “...because it sets boundaries right”, reminds Grimmelmann (Grimmelmann 2010).

For accepting it we are indeed in need of a critical perception regarding media commons (h)activism among netizens safeguarding leftovers of freespeech not yet privately owned.

\section{Conclusion}

"The humanities are thriving, but not in the academy. Homo sapiens has always hungered for story and song. We are narrative and rhythmical creatures." 18

While encouraging further study of knowledge and learning horizons by illuminating the role that information literacy instruction could play in creating citizens capable of applying critical skills in their daily lives and attributing it with professional responsibility in developing an informed, reasoning public space, we are truly engaging ourselves in discourses on horizons of effective participation in a democratic society. Critical mediation cannot be developed or achieved without acknowledgment that strict "neutrality" is an illusory position within the context of global educational settings driven by the neoliberal agenda of the New Public Management. In other words, critical pedagogists in default language, recognize that information ethics and social responsibility should be the next steps towards development of critical information literacy curriculum as well as its systemic inclusion in academic librarianship. Samek has already conducted extremely important work in terms of outlining the framework of topics in which librarians' literacy advances dwell ${ }^{19}$, emphasizing challenges for contemporary academic and learning practices ${ }^{20}$, providing useful insight for improvements in critical research methodology in general. Progressing and enhancing aspirations of those librarians, students, teachers and researchers whose supporting academic initiatives can create new spaces for getting involved in the demanding area of information and communication sciences as well as critical media studies is just one

\footnotetext{
18 Warren, Rosanna. “The Decline of the Humanities - and Civilization". New Republic (July $17^{\text {th }}, 2013$.). Available at: http://www.newrepublic.com/article/113763/why-we-need-liberalarts\#(21.7.2013.)

19 Samek, Toni. Librarianship and Human Rights. Oxford: Chandos Publishing, 2007.

20 Samek, Toni. "Information ethics and the corporatist academic enterprise: critical implications for education of library and information workers." Revista EDICIC. Vol. 1. No. 1. (2011). Available at: http://www.edicic.org/revista/index.php?journal=RevistaEDICIC\&page=article\& op=view\&path[]=5 (22.02.2012).
} 
of the layers, not its primary focus. For empowering users to root research activities into a more refined background, information literacy guidelines should start with critical pedagogy being a prerequisite in the development of innovative network modules. Surely such initiative commonly invites us all to participate in deeper considerations of what communities need that would, hopefully, end up in a shift towards digital humanities that refers to "new modes of scholarship and institutional unites for collaborative, transdisciplinary, and computationally engaged research, teaching, and publication" (Burdick et al., 2012).

Teaching lifelong methodologies such as information literacy is the best way to cope with a quantitative world of information. The most recent studies clearly show that students want education "(or shall we call it "training"?) that will prepare them for jobs in this era of practicality and materialism"(Warren 2013). Investing in 'thinking about thinking' not only escapes disciplines that favour syntactical and pragmatic - valueswhen information literacy is discussed, but semantic instructors should also commit themselves in guiding users to think about how they think (and how their thinking leads them to solution sets rather than a singularly determined answer). Hierarchies and standards in the growing appetites for new knowledge construction asks for substantial shifts, distancing from positivistic trademarks by which valid knowledge is objective, empirical and static; beliefs and practices based on materialist textualities and literacies (simplified construction of rationality) that instrumentalizes imaginative and the creative power of questioning. The learning requests openness, political awareness, and new teaching paradigms which information literacy courses and discourses should mirror in its basics as well as in its future networked prospects, adhering close to its critical, social epistemological, why not say, (un)commons values.

\section{References}

Accardi, Maria T., Emily Drabinski and Alana Kumbier (eds.) (2010). Critical Library Instruction - Theories and Methods. Eds. Duluth, MN: Library Juice Press.

Apple Michael W. (1990). Ideology and Curriculum. New York: Routledge.

Benkler Yochai (2003). "Freedom In The Commons: Towards Political Economy Of Information." Duke Law Journal. 52 (124). Available at: http://scholarship.law. duke.edu/cgi/viewcontent.cgi?article $=1191 \&$ context $=\mathrm{dlj}($ accessed 23.4.2010)

Bollier David, Helfrich Silke (eds.) (2012). The Wealth of the Commons. A World Beyond Market and State. Commons Strategies Group. Levellers Press.

Burdick, Anne et al. (2012). Digital Humanities. Cambridge, MA; London: MIT Press. Available at: http://mitpress.mit.edu/sites/default/files/titles/ content/9780262018470_Open_Access_Edition.pdf (accessed 12.03.2013). 
Coleman Gabriella E. (2013). Coding freedom: The ethics and aesthetics of hacking. Princeton: Princeton University Press.

Coleman Gabriella E. "Hacker". The John Hopkins Encyclopaedia of Digital Textuality (Forthcoming, 2014). Available at: http://gabriellacoleman.org/wpcontent/uploads/2013/04/Coleman-Hacker-John-Hopkins-2013-Final. (accessed 22.7.2013).

Freire Paolo (2002). Pedagogija obespravljenih. Zagreb: Odraz.

Giroux Henry (2013). Henry Giroux: The Necessity of Critical Pedagogy in Dark Times. Interviewed by Jose Maria Barroso Tristan. Global Education Magazine (6 February 2013). Available at: http://truth-out.org/news/item/14331-a-criticalinterview-with-henry-giroux (accessed 25.03.2013)

Giroux Henry A. (1984). "Public Philosophy and the Crisis in Education." Harvard Educational Review Vol. 54. No. 2.

Giroux Henry (2013). “Teški rat" protiv američke mladeži”. Interviewed by Hrvoje Šimčević. H-Alter. (4 January 2013). Available at: http://www.h-alter.org/vijesti/ svijet/teski-rat-protiv-americke-mladezi (accessed 19.1.2013).

Grimmelmann James (2010). "The Internet is a semicommons." Fordham Law Review Vol. 78. Available at: http://works.bepress.com/cgi/viewcontent. cgi? article $=1030 \&$ context $=$ james_grimmelmann $($ accessed 13.04.2011).

Hansen Mark B. N., and William J. Thomas Mitchell (2010). “The introduction to Critical Terms for Media Studies.” Critical Terms for Media Studies. Eds. Hansen, Mark B. N., and William J. Thomas Mitchell. Chicago: University of Chicago Press. Available at: http://www.press.uchicago.edu/Misc/Chicago/532554.html (accessed 12.05.2013).

Kaptizke Cushla (2003). “(In)formation literacy: A positivist epistemology and a politics of (out)formation.” Educational Theory 53.1. Available at: eprints.qut. edu.au/5876/1/5876.pdf (accessed 15.02.2011).

Lankes David R. (2011). The Atlas of New Librarianship. Cambridge, MA: MIT Press.

Morozov Evgeny (2011). The Net Delusion: The Dark Side of Internet Freedom. New York: Public Affairs.

Morozov Evgeny (2009). "How the Net aids dictatorships.” TED (July, 2009). Available at: http://www.ted.com/talks/evgeny_morozov_is_the_internet_what_orwell_ feared.html (accessed 14.02.2010).

Poster Mark (2001). “Citizens, digital media and globalization.” Mots Pluriels No. 18. (Aug. 2001). Available at: http://motspluriels.arts.uwa.edu.au/MP1801mp.html (accessed 29.11.2009).

Price Gareth (2013). “Aaron Swartz: A Libertarian Dilemma”. Huffington Post Politics Blog (22 January 2013). Available at: http://www.huffingtonpost.com/ garethprice/aaron-swartz-the-politics_b_2518172.html (accessed 15.02.2013).

Radford Gary P. (2008). "Flaubert, Foucault, and the Bibliotheque Fantastique: Toward a Postmodern Epistemology for Library Science.” Library Trends Vol. 46. No. 4. Available at: http://www.ideals.illinois.edu/bitstream/handle/2142/8181/ librarytrendsv46i4d_opt.pdf (accessed 15.06. 2009).

Ruggerio Greg (2012). “Occupying with Noam Chomsky”. In: Occupy, Noam Chomsky. London: Penguin Books. 
Samek Toni; professor at the School of Library and Information Studies, University of Alberta. Interview 16.07.2012.

Samek Toni (2007). Librarianship and Human Rights. Oxford: Chandos Publishing.

Samek Toni (2011). "Information ethics and the corporatist academic enterprise: critical implications for education of library and information workers." Revista EDICIC. Vol .1 No. 1. Available at: http://www.edicic.org/revista/index.php?journal=Revis taEDICIC\&page $=$ article\&op $=$ view\&path[] $=5$ (accessed 22.02.2012).

Samek Toni (2013). "You Can't Hurry Love": Slow Library Education in Culturally Diverse Society. Paper presented at: IFLA World Library and Information Congress, 17 - 23 August 2013, Singapore. Available at: http://library.ifla.org/98/ (accessed 30.7.2013).

Torrell Margaret Rose (2010). "Negotiating Virtual Contact Zones: Revolutions in the Role of the Research Workshop." Critical Library Instruction - Theories and Methods. Eds. Accardi, Maria T., Emily Drabinski and Alana Kumbier. Duluth, MN: Library Juice Press, Pg. 94.

WarkMcKenzie (2004). A Hacker Manifesto. Cambridge, MA: Harvard University Press. Available at: http://web.mit.edu/cms/Events/mit2/Abstracts/mckenziewark.pdf (accessed17.05.2011).

Warren Rosanna (2013). "The Decline of the Humanities - and Civilization". New Republic (17 July 2013). Available at: http://www.newrepublic.com/ article/113763/why-we-need-liberal-arts\# (accessed 21.7.2013).

Žižek Slavoj (2013). “Trouble in Paradise”. London Review of Books Vol. 35. No. 14. (18 July 2013). Available at: http://www.lrb.co.uk/v35/n14/slavoj-zizek/troublein-paradise (accessed 11.7.2013).

\section{Krytyczne kompetencje - otwarte wartości, wyobrażona racjonalność}

Artykuł dąży do podkreślenia dyskusji o relacji między pozytywizmem, krytyczną pedagogiką i charakterystyczną dla nowych mediów polityką wytwarzania informacji i wiedzy; założenie wstępne powiada, że krytyczny tryb informacji jest dużo bardziej problematyczny niż cyfrowy. Innymi słowy, skoro standaryzacja kompetencji informatycznych ma swoje granice w zachowywaniu niezapośredniczonej autentyczności i znaczenia, takie stanowisko wywołuje problem w uznaniu zasadniczych miejsc analizy cyfrowej epistemologii współczesności. To ostatnie zjawisko powinno obejmować występowanie na rzecz krytycznych mediów, kompetencji i etyki jako kluczowych składników odpowiedzialnego społecznie wytwarzania i rozpowszechniania informacji w nowej domenie publicznej: w Internecie. Kiedy praktyki wspólnego lub p2p, opartego na uwspólnianiu, wytwarzania wiedzy nie są ani w pełni rozumiane, ani aktualizowane w nowoczesnej edukacji, wówczas wolne/otwarte rozpowszechnianie (cyfrowych) zasobów jest hamowane przez dyskursy zinstrumentalizowanej (kulturalistycznej) depolityzacji w skomodyfikowanym społeczeństwie informacyjnym. Z te- 
go powodu opowiadam się za krytyką modeli kompetencji informacyjnych przy wykorzystaniu Paolo Freire'a koncepcji banking model edukacji i haktywizmu oraz krytycznego stanowiska wobec profesjonalnych stanowisk.

\section{Kritička pismenost - otvorene vrijednosti, imaginarna racionalnost}

Ovaj rad ima za cilj naglasiti važnost diskutiranja odnosa između pozitivizma, kritičke pedagogije i politika novomedijske proizvodnje informacija i znanja, ističući kako je kritički informacijski jaz daleko problematičniji od digitalnog. Drugim riječima, ako standardizacija kompetencija informacijske pismenosti pokazuje svoja ograničenja u vezi sa zadržavanjem na nepristrasnosti, autentičnosti i relevantnosti onda se deficit prepoznavanja ključnih tačaka za analize prijepora u domenu digitalne epistemologije ukazuje kao anahronost. Upravo zato bi bilo potrebno zagovarati kritičke medijske studije, kritičku pismenost i etiku kao ključne komponente društveno odgovorne proizvodnje i distribucije informacija u novom javnom prostoru Mreže. Kada se prakse kolaborativne proizvodnje znanja odnosno tzv. p2p proizvodnje zajedničkih dobara (commons) nedovljno razumiju onda se ne može očekivati ni njihova aktualizacija $u$ suvremenim obrazovnim modelima koji slobodno/otvoreno upravljanje digitalnim resursima prepuštaju instrumentaliziranim kulturološkim diskursima komodificiranog informacijskog društva. Iz tog razloga, tvrdim kako propitivanje modela informacijske pismenosti treba izložiti kritičkoj pedagogiji odnosno kritici bankarskog modela obrazovanja, haktivizmu, kao i tvrdnji Toni Samek kako "nema ništa praktičnije od učenja kako graditi samopouzdanje za diskusije o profesionalnim stavovima braneći ga kroz kritiku, a ne opstruktivnost”. 